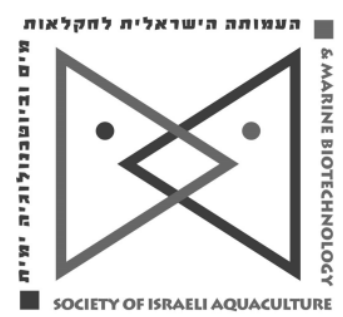

The IJA appears exclusively as a peer-reviewed on-line open-access journal at http://www.siamb.org.il. To read papers free of charge, please register online at registration form.

Sale of $I J A$ papers is strictly forbidden.

\title{
The Nutrient Digestibility of Commercial and Farm- Prepared Feeds for Onchorynchus mykiss, Dicentrarchus labrax, and Salmo trutta labrax
}

\author{
İlhan Yandı ${ }^{1} *$, Süleyman Akhan ${ }^{2}$, Atilla Özdemir ${ }^{3}$, Sedef Işıdan $^{3}$ \\ Uğur Cansın Ödün ${ }^{4}$, \\ ${ }^{1}$ Maritime Faculty, Recep Tayyip Erdogan University \\ ${ }^{2}$ Faculty of Fisheries, Akdeniz University \\ ${ }^{3}$ Republic of Turkey Ministry of Food, Agriculture and Livestock \\ ${ }^{4}$ Faculty of Fisheries, Recep Tayyip Erdogan University
}

Keywords: protein; lipid; digestibility

\begin{abstract}
We compared the digestion rate of commercial, and farm-prepared feeds, in three species (Onchorynchus mykiss, Dicentrarchus labrax, and Salmo trutta labrax) reared at two temperatures $\left(12^{\circ} \mathrm{C}\right.$ and $\left.17^{\circ} \mathrm{C}\right)$. Rearing conditions, except for hydrodynamic conditions of the offshore farms, were simulated in the experiment. There were significant differences in overall digestibility between the diets; overall protein digestibility of the farm-prepared feed was much higher than that of the commercial feed $(P<0.01)$. Lipid digestibility of farm-prepared diets was competitive but not significant compared to commercial feeds. The results may be attributed to poorly digestible ingredients of commercial feeds while farm-prepared feeds include mainly fresh anchovy and other ingredients such as hardtack meal, corn meal, wheat flour, and soybean meal. Consequently, farm-prepared diets seem to be much more competitive in respect to both digestibility, and cost, compared to commercial diets. In addition, the nutrient digestion rate of farm-prepared feeds was more balanced and stable.
\end{abstract}

\footnotetext{
* Corresponding author. Tel.: +905444290553, fax: +904643111072, e-mail: ilhan.yandi@erdogan.edu.tr
} 


\section{Introduction}

In fish culture, fish nutrition depends on commercial feeds, and $50-70 \%$ of production costs are due to feed expenses (Hasan, 2007; White, 2013). Use of the lowest cost formulation of diets may contain ingredients which may cause a change in protein and lipid digestibility. Even different feed batches produced by the same company may have different biochemical characteristics and digestibility, and eventually may vary in quality. Features of diet ingredients used in commercial feeds are important to maximize the nutrient digestibility, and to minimize the environmental impact of aquaculture on the marine ecosystem.

Feeds and feeding patterns also have important effects on growth performance, feed utilization, and fish meat quality (Johansson et al., 1995; Storebakken and Austreng, 1987). Environmentally friendly feeds should be improved, and new feeding strategies implemented to alleviate environmental damage caused by aquaculture (Lopez Alvarado, 1997). Detrimental environmental effects of aquaculture, caused primarily by uneaten feed and fish feces have become the focus of attention in recent years (Akhan and Gedik, 2011). A national research project was carried out to evaluate the environmental impact of aquaculture in the Black and the Aegean seas since organic waste may be a problem that impacts on the carrying capacity of the area around the fish cages (Karakoc et al., 2010).

In offshore systems most cultured marine fish species are carnivorous. Culturing carnivorous fish species requires high-quality fish meal and fish oil obtained from forage fish as they are the main, necessary sources of essential amino acids and fatty acids (Oliva-Teles et al., 2015). However, global forage fish stock such as herring, anchovy, sardine, sprat, and capelin, that are often processed as fishmeal, have reached a critically low level and are unable to meet the increasing demands of aquaculture (FAO, 2016). Fishmeal and fish oil prices have increased and this phenomenon has forced local farms in the vicinity of the Black Sea coast to find both practical and economic alternatives. Some farms have produced their feed using local or imported fish meal to reduce feed costs, while others use frozen anchovies to produce their feed. Black Sea anchovy which is a pelagic, planktivorous, fast-growing, small sized, schooling forage fish and particularly abundant in the Black Sea ecosystem accounts for more than $60 \%$ of total Turkish catches of marine fish (TurkStat, 2015). Farms using these fish in their formulations use anchovy when the price is low, and deep freeze them until needed.

There is no data reflecting the differences in digestibility of commercial and farmprepared diets. The current experiment was coordinated with the farmers to achieve optimal results. Local farmers supplied the fish and the diets for this study, and the digestibility measurements were made according to acid-insoluble ash (AIA) markers. This study is the first attempt to evaluate diets used in offshore cages in the Black Sea ecosystem.

Fish material and adaptation

\section{Materials and Methods}

Rainbow trout (Oncorhynchus mykiss), Black Sea trout (Salmo trutta labrax), and sea bass (Dicentrarchus labrax), were obtained from stocks held in offshore farms and brought to the Aquaculture Facility of the Central Fisheries Research Institute (CFRI), Trabzon. All species were divided into two size groups, small and large, according to the typical production strategy of local offshore farms: rainbow trout weighing $301 \mathrm{~g}(\mathrm{n}=$ $210)$ and $920 \mathrm{~g}(n=68)$, sea bass $120 \mathrm{~g}(\mathrm{n}=516)$ and $450 \mathrm{~g}(\mathrm{n}=137)$, Black Sea trout $250 \mathrm{~g}(\mathrm{n}=248)$ and $550 \mathrm{~g}(\mathrm{n}=113)$ average initial small and large body weights, respectively. The fish were acclimated for two weeks in outdoor circular fiberglass tanks $\left(6 \mathrm{~m}^{3}\right)$ and fed with 4-8 $\mathrm{mm}$ commercial pellets twice a day, morning and afternoon. The tanks were supplied with brackish water (17 ppt) with ten $\mu$ filters and UV-treated. Constant aeration was supplied equally for each tank. The oxygen concentrations, measured in the tanks, ranged from $8.2-8.7 \mathrm{mg} / \mathrm{L}$. Water temperature was set at $15^{\circ} \mathrm{C}$, at a flow rate which was adjusted to $0.55 \mathrm{~L} / \mathrm{sec}$ amount per tank. Before the experiment, the fish were fasted for two days in adaptation tanks after which they were randomly 
distributed to the experimental tanks equipped with feces collection and specifically designed for the current digestibility experiment.

Experimental feeds.

The feeds used in this experiment were commercial extruded diets produced by three different companies, and farm-prepared feeds (ingredients: whole anchovy, hardtack meal, corn meal, wheat flour, soybean meal). Farm-made feeds were made by incorporating whole anchovy and the other ingredients without heat treatment until the desired diet texture was reached according to the routine experience of the farmers. To conserve the consistency of farm-made feeds, the farmers were requested to prepare their fish feed as usual. The proximate compositions of these appear in Table 1.

Table 1. Proximate composition of the experimental diets

\begin{tabular}{llccccc}
\hline Diet source & Diet type & Size $(\mathrm{mm})$ & $C P(\%)^{*}$ & $C L(\%)^{*}$ & Ash (\%)* & DM (\%) \\
\hline \multirow{4}{*}{ Com-1 } & Trout & 4 & 41.78 & 16.95 & 5.41 & 89.67 \\
& Trout & 8 & 41.22 & 16.66 & 6.22 & 90.62 \\
& Sea bass & 4 & 42.17 & 19.45 & 5.87 & 92.72 \\
& Sea bass & 8 & 42.33 & 19.64 & 5.91 & 92.50 \\
\hline \multirow{5}{*}{ Com-2 } & Trout & 4 & 41.28 & 16.12 & 7.21 & 93.44 \\
& Trout & 8 & 41.55 & 16.72 & 7.02 & 93.21 \\
& Sea bass & 4 & 42.34 & 18.42 & 6.02 & 86.80 \\
& Sea bass & 8 & 42.29 & 19.92 & 9.23 & 96.24 \\
\hline \multirow{5}{*}{ Com-3 } & Trout & 4 & 40.07 & 16.05 & 7.33 & 91.91 \\
& Trout & 8 & 39.84 & 16.22 & 7.55 & 90.95 \\
& Sea bass & 4 & 40.10 & 18.90 & 8.63 & 92.95 \\
& Sea bass & 8 & 40.18 & 19.00 & 8.51 & 92.55 \\
\hline \multirow{5}{*}{ Farm-made } & Trout & 4 & 40.19 & 14.87 & 6.11 & 86.92 \\
& Trout & 8 & 39.93 & 14.75 & 6.08 & 86.68 \\
& Sea bass** & 4 & 29.42 & 18.90 & 6.11 & 67.92 \\
& Sea bass** & 8 & 28.72 & 20.38 & 5.66 & 70.56 \\
\hline
\end{tabular}

*Results were given as dry matter basis

** Frozen anchovies were used for feed production by farmer

CP: crude protein, CL: crude lipid, DM: dry matter, Com: company brand

$4 \mathrm{~mm}$ feeds were fed to small size fish; $8 \mathrm{~mm}$ feeds were fed to large size fish.

\section{Digestibility}

The digestibility experiments were carried out with rainbow trout (Oncorhynchus mykiss), sea bass (Dicentrarchus labrax) and Black Sea Trout (Salmo trutta labrax) in the aquaculture facility of the Central Fisheries Research Institute (CFRI), Trabzon. After an adaptation period in large tanks, fish were transferred to indoor experimental tanks. The digestion experiment was conducted over a period of 4 weeks (including the first 2 weeks of adaptation to the experimental conditions). A total of 48 treatments were applied to the three species, two size groups for each, four different feed sources, and two temperatures. The 8 circular tanks used in each repetition of the experiment, (six repetitions overall) were made of dark-green fiberglass with a diameter of $2 \mathrm{~m}$ and a volume of $3 \mathrm{~m}^{3}$. For each of the size groups and species, separate diets were formulated. After terminating the low-temperature treatment $\left(12^{\circ} \mathrm{C}\right)$ the water was set to a higher temperature $\left(17^{\circ} \mathrm{C}\right)$.

The experimental tanks were set up in a randomized design. The average stocking density at the beginning of the experiment ranged between $2.6-3.1 \mathrm{~kg} / \mathrm{m}^{3}$. The water outlet, centrally located at the bottom of the tanks, and the wastewater passed through the feces collector and digestion rate of the feeds was monitored. Rearing conditions simulated offshore culture conditions in the Black Sea. Tanks were supplied with $1 \mu$ filter and UV-treated seawater pumped from a depth of $56 \mathrm{~m}$ under the sea. Water temperature was set to $12 \pm 0.25^{\circ} \mathrm{C}$ and $17 \pm 0.35^{\circ} \mathrm{C}$ (mean $\pm \mathrm{SD}$ ), salinity level was kept at $17.4 \pm 0.2 \%$ (mean $\pm \mathrm{SD}$ ), and oxygen saturation level was kept slightly over $100 \%$. Throughout the experiment, photoperiod regime was $16 \mathrm{~h}$ light: $8 \mathrm{~h}$ darkness, as 
in natural seasonal conditions. Feed was randomly distributed in separate rows of tanks in order to minimize possible local effects. The fish were fed a daily ration of $10 \mathrm{~g} / \mathrm{kg}$ body weight in low-temperature conditions and $20 \mathrm{~g} / \mathrm{kg}$ feed in the high temperature ones, twice daily. After feeding, uneaten feed and partially dissolved feed were immediately removed from the experimental tank via the drain valve to avoid overestimation of nutrient digestibility of experimental feeds.

Feces were collected as described by Austreng (1978), and acid insoluble ash (AIA) was used as the inert marker (Atkinson et al., 1984). Collected fish feces from each tank were pooled and stored for analysis. Fecal collection was conducted daily over 5-10 days to obtain sufficient amounts for analysis.

Chemical analyses of experimental feeds and feces

Approximately $0.5 \mathrm{~kg}$ of feed from each feed sample was homogenized in a grinder. Feces $(0.3-0.5 \mathrm{~kg})$ were freeze-dried and homogenized. Analysis of diets and feces for dry matter, ash, crude protein, and crude fat were conducted according to official methods (Helrich, 1990).

Calculations and statistics

Analysis of diets and fecal samples were performed in the Fish Nutrition Laboratory at CFRI, Trabzon. AIA content of diets and feces were determined by the method of Atkinson et al. (1984). All analyses were performed as triplicate. The digestibility of commercial and farm-made feeds by the three cultured species was evaluated for temperature and fish size for each species separately. Apparent nutrient digestibility (AND) for protein and lipid were calculated as follows:

AND $(\%)=100-\left(100 \times\left(\frac{\% \text { indicator in diet }}{\% \text { indicator in feces }} \times \frac{\% \text { nutrient in feces }}{\% \text { nutrient in diet }}\right)\right)$

All statistical analyses were performed using Minitab 17.0 and SigmaPlot 14.0. Variance analyses were carried out using the General Linear Models (GLM) procedure of the Minitab. To assess normality of distributions, a Kolmogorov-Smirnov test was used and homogeneity of variances was tested using $\mathrm{F}$ test. The data that failed the Normality Test (Kolmogorov-Smirnov) $(P<0.05)$ was transformed to produce normal distribution then ANOVA comparison was applied. Two-way and three-way ANOVA were used to test data on mean digestibility of protein and lipid at different conditions, as well as the overall data for digestibility were followed by Holm-Sidak post-hoc method in the case of significant ANOVAs, $P<0.01$. All conditions were tested to detect the effect of the feeds.

\section{Results}

Fish readily accepted the given diets and no mortality was observed in any of the experimental tanks. Apparent nutrient digestibility (AND) of crude protein and crude fat for fish fed the commercial and farm-produced feeds were calculated, and fish species were evaluated separately based on internal AIA (Fig. 1 and Fig. 2). 

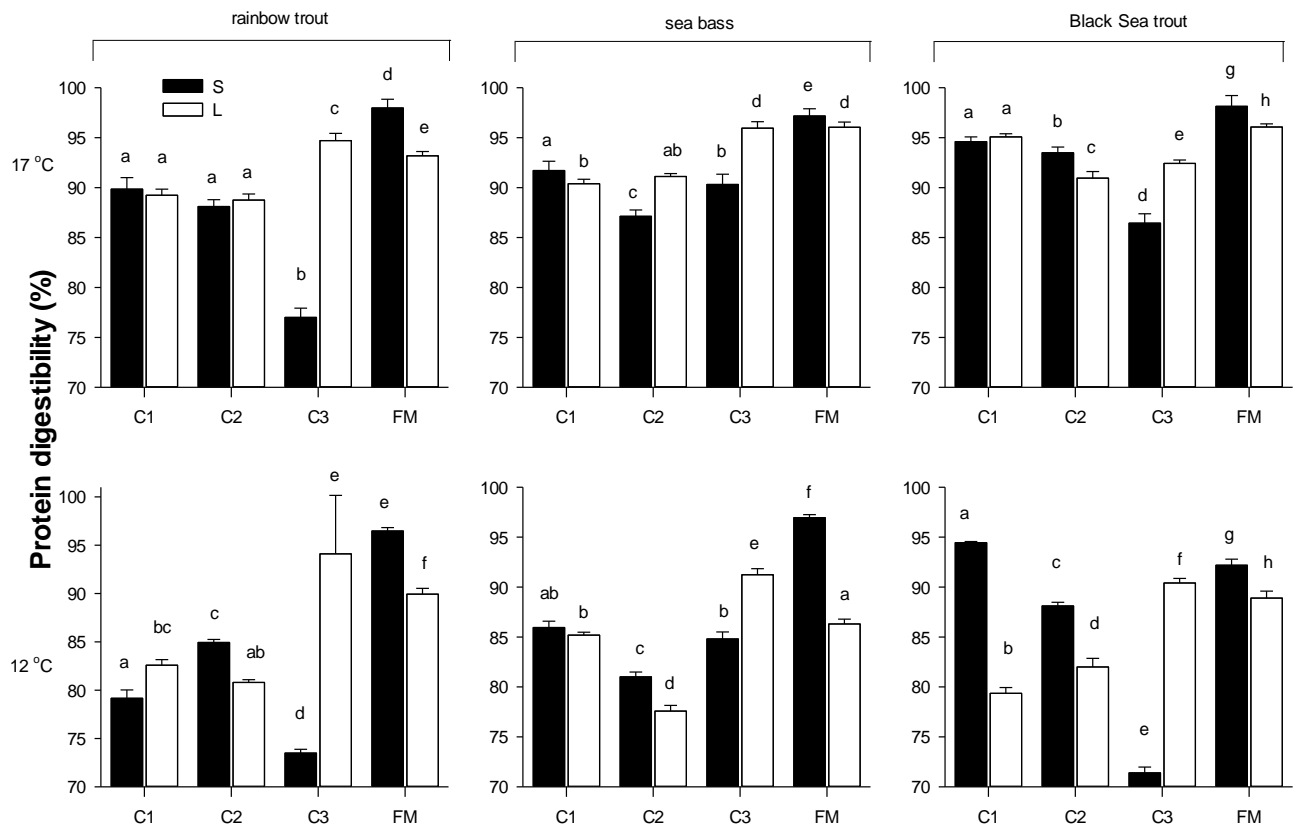

Fig. 1. Protein digestion rate of rainbow trout, sea bass and Black Sea trout reared at two temperatures $\left(12^{\circ} \mathrm{C}\right.$ and $\left.17^{\circ} \mathrm{C}\right)$ with commercial and farm-made diets.

C1, C2, C3 represent different commercial feeds while FM represents farm-made feed.

Small size and large size fish were evaluated for each experimental regime; black bars $(S)=s m a l l$ size group, while white bars $(L)=$ large size group. Vertical line indicates standard error of the mean (S.E.). Different letters indicate significant difference based on feed of the different fish species in percent protein digestion rate trajectories (ANOVA, All Pairwise Multiple Comparison Procedures by Holm-Sidak method), $P<0.01$. The data failed by Normality Test (KolmogorovSmirnov) $(P<0.050)$ was transformed to produce normal distribution then ANOVA comparison applied. Overall interaction between temperature, fish species and fish size on feed digestibility, farm-made diet was significant (three-way nested ANCOVA, $P<0.05$ ).

Rainbow trout. Both in high and low temperatures, protein digestibility of farm-made diets was significantly higher than with the commercial ones in both the small and large groups $(p<0.01)$ with the exception of the large size group fed C3 commercial diet (Fig. $1)$. The highest protein digestion rate was recorded in the small size group as $97.97 \%$ \pm 0.44 fed with the farm-made feed at $17^{\circ} \mathrm{C}$. Protein digestibility of farm feeds varied according to fish length and water temperature. Protein digestion was found to be higher and statistically significant in small fishes $(P<0.01)$ for farm-made feeds. Lipid digestion was higher and statistically significant in small fish except in low temperature $(P<0.01)$. Digestibility rates determined are lower for all feeds at low water temperatures $\left(12^{\circ} \mathrm{C}\right)$. The lowest protein digestion rate was $77.0 \% \pm 0.47$ in the small group fed the C3 feed (4 $\mathrm{mm}$ ). Significant variations were also recorded between feed pellets of $4 \mathrm{~mm}$ and $8 \mathrm{~mm}$ from the C3 group however their proximate compositions were similar.

Lipid digestion rate: in the small group fed farm-made feed it was significantly higher than the other groups $(P<0.01)$. The highest value was $96.51 \% \pm 0.29$ and $97.84 \%$ \pm 0.87 . When the overall interaction between fish size and temperature were analyzed, the lipid digestion rate of farm-made feed was high but not significantly different (Fig. 2). 

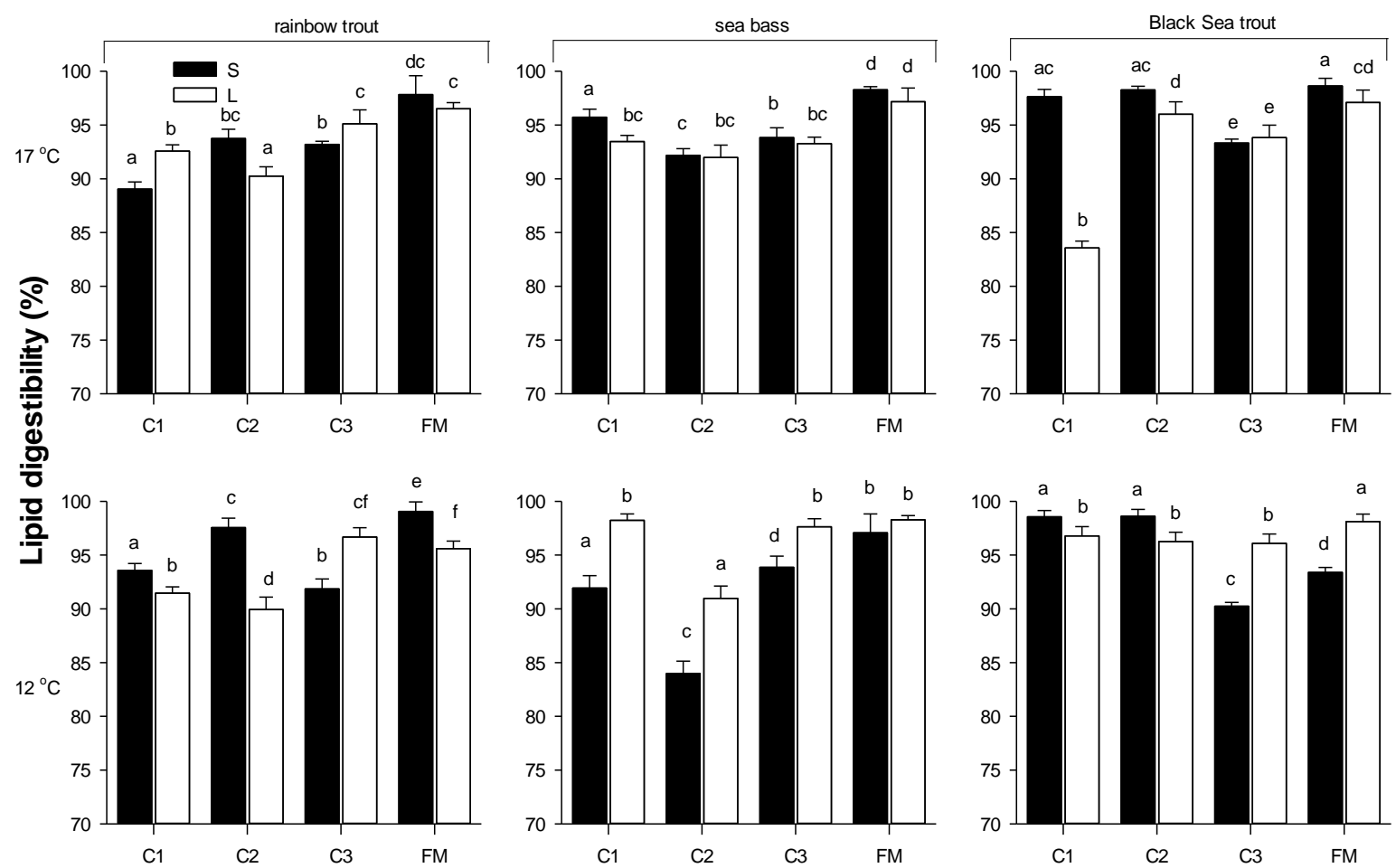

Fig. 2. Lipid digestion rate of rainbow trout, sea bass, and Black Sea trout reared at two temperatures $\left(12^{\circ} \mathrm{C}\right.$ and $\left.17^{\circ} \mathrm{C}\right)$ with commercial and farm-made diets.

C1, C2, C3 represent different commercial diets while FM represents farm-made diet. Small size and large size fish were evaluated for each experimental regime; black bars $(\mathrm{S})$ = small size group, while white bars $(L)=$ large size group. Vertical line indicates standard error of the mean (S.E.). Different letters above the bars indicate significant difference based on feed for given fish species in percent protein digestion rate trajectories (ANOVA, All Pairwise Multiple Comparison Procedures by Holm-Sidak method), $P<0.01$. The data failed by the Normality Test (Kolmogorov-Smirnov) ( $P$ $<0.050$ ) was transformed to produce normal distribution then ANOVA comparison applied.

Overall interaction between temperature, fish species and fish size on feed digestibility, there was no significant difference among feeds (three-way nested ANCOVA, P > 0.05).

Sea bass. The highest protein digestion rates in fish reared with farm-made feeds ranged between $96.04 \% \pm 0.26$ and $97.17 \% \pm 0.36$. Protein digestibility of farm-made feeds was higher than commercial feeds $(\mathrm{P}<0.01)$ (Fig. 1 ) at $17^{\circ} \mathrm{C}$. Protein digestibility of commercial feeds was lower than in the $\mathrm{C} 3$ diet groups in large sea bass at $12^{\circ} \mathrm{C}$. Lipid digestion rate of farm-made diets seemed fairly balanced and high $(98.28 \% \pm 0.14)$ (Fig. 2). No significant difference was recorded in lipid digestibility.

Black Sea trout. The highest protein digestion rate occurred in fish fed the farm-made diet at $17^{\circ} \mathrm{C}(98.14 \% \pm 0.54)$. The highest rate in the $\mathrm{C} 1$ group at $12^{\circ} \mathrm{C}$ was $94.44 \%$ \pm 0.06 (Fig. 1). Protein digestibility of farm-made feeds was significantly higher in the small size Black Sea trout at $17^{\circ} \mathrm{C}$. There was no significant difference in the lipid digestion rate of the feeds.

Overall interaction of temperature, fish species, and fish size, on protein digestibility with farm-made feeds were significant (three-way nested ANCOVA, $P<0.05$ ). Significant variations were detected in C3 for rainbow trout and Black Sea trout in low temperature. No significant differences were observed on lipid digestibility. Lipid digestibility of commercial feeds was higher than protein digestibility.

\section{Discussion}

Offshore farms in the Black Sea have enjoyed rapid development of expanding Turkish aquaculture. Rainbow trout, seabass, and Black Sea trout are cultured in offshore cages (TurkStat, 2015). Some fish farms in the Black Sea produce and use self-formulated feed due to cost, confidence in existing commercial feeds [Black Sea offshore farmers have 
complained about the feed conversion ratio (FCR), and the cost of commercial feeds], efficiency, and sustainability. In recent years, many farms have compared commercial feeds with their own produced feeds and found that their feed was more efficient both in growth and cost, but since no scientific research has been done these reports were not based on scientific data.

Feed quality is very important in order to maximize the nutrient digestibility, and minimize the environmental impact, of aquaculture on the marine ecosystem however some raw materials in production may have a negative effect on nutrient digestibility (White, 2013). The old "press technology", and often unsterile conditions, have been used in the production of farm-made diets and this in turn may have affected food quality based on fish health; the question is what is the digestibility of these diets when compared to commercial ones?

This study evaluated the nutrient digestion rate of three species reared with commercial and farm-made feeds at two temperatures $\left(12^{\circ} \mathrm{C}\right.$ and $\left.17^{\circ} \mathrm{C}\right)$. In this experiment we tried to simulate the environmental conditions of offshore cages as closely as possible with feed, stocking density, fish size, temperature, and salinity. However it is impossible to accurately simulate the hydrodynamic conditions at sea. The initial stocking density was $2.6 \mathrm{~kg} / \mathrm{m}^{3}$ and reached approximately $3.5-4.6 \mathrm{~kg} / \mathrm{m}^{3}$. In practice, traditional production of offshore farms ranges from $1-3 \mathrm{~kg} / \mathrm{m}^{3}$ to $10-15 \mathrm{~kg} / \mathrm{m}^{3}$. Therefore our stocking density can be considered acceptable for our simulative approach. Traditionally, two size groups (small $100-300 \mathrm{~g}$, and large $600 \mathrm{~g}<$ ) are placed in offshore cages in Black Sea. We therefore simulated this production strategy here.

The AIA method that was adopted here is an ideal inert indicator for digestibility (Tacon and Rodriguez, 1984), in numerous fish species (Atkinson et al., 1984; Shahat, 1993; De Silva and Anderson, 1995; Gurure at al., 1996; Goddard and McLean, 2001).

There were significant differences in overall digestibility between diets. Protein digestibility of the farm-made diets was highly significantly greater than the commercial feeds $(P<0.01)$. This may be attributed to poorly digestible ingredients in these while farm-made feeds include mainly fresh anchovy which has higher nutrient digestibility, together with other ingredients. Lipid digestibility of farm-made diets was competitive but not significantly different. On the other hand, lipid digestibility of commercial feeds was higher than their protein digestibility. The lipid digestibility varies with the raw source material in the feed, as well as from species to species (Degani at al., 1997). This result may be attributed to the use of fish oil in commercial feeds. However, aquafeed companies rarely divulge ingredients used in their feeds. Similarly, the results of high dry matter and protein utilization were reported in rainbow trout (Azevedo et al. 1998) and in channel catfish (Buentello et al. 2000).

Protein and lipid digestibility of modern aquafeeds was reported to be greater than $90 \%$ in rainbow trout at $13-17^{\circ} \mathrm{C}$ (Rasmussen and Jokumsen, 2009). In this study, protein and lipid digestion rates of commercial and farm-made feeds varied and depended on fish species, fish size, and water temperature. The digestion rate of some commercial diets was less than 90\%. Farm-made diets showed better performance than commercial ones. Further research, such as FCR, specific growth rate (SGR), feed consumption, is needed to understand if these farm-made diets meet the nutritional requirements of cultured fish for normal growth.

The use of high quality and digestible fish feed is crucial to minimize negative environmental impact of fish farms. Farm-made diets can be considered more environmentally friendly compared to commercial feeds.

Based on our results farm-made diets seem competitive compared to commercial feeds used in the Black Sea. Ensuring the continuity of cheaper frozen anchovy supply seems the only problem for the future. Farm-made diets will continue to be highly competitive as long as enough forage anchovy is supplied. Cold storage of anchovy for the local farmers is important to prevent contamination by fungus and bacteria.

The idea of farmers producing their own food appears to be a necessity of market conditions rather than a preference. However farmers must also consider the concerns of offshore sustainability, as well as the environmental impact of their farms. 


\section{Acknowledgements}

This research was supported by a grant from the TUBITAK (Project no: 106G094). We would like to thank the owners and staff of the farms for their cooperation and for their valuable contributions.

\section{References}

Akhan S. and K. Gedik, 2011. The nutrient releases from sea bass (Dicentrarchus labrax Linnaeus, 1758) faecesand food in estuarine Black Sea condition. J. Food Agric. Environ., 9(1): 738-740.

Atkinson J. L., Hilton, J. W. and S. J. Slinger, 1984. Evaluation of Acid-Insoluble Ash as an Indicator of Feed Digestibility in Rainbow-Trout (Salmo-Gairdneri). Can. J. Fish. Aquat. Sci., 41(9): 1384-1386.

Austreng, E., 1978. Digestibility determination in fish using chromic oxide marking and analysis of content from different segments of gastro-intestinal tract. Aquaculture, 13 (3): 265-272.

Azevedo P. A., Cho C.Y. and D.P. Bureau, 1998. Effects of feeding level and water temperature on growth, nutrient and energy utilization and waste outputs of rainbow trout (Oncorhynchus mykiss). Aquat. Living Resour., 11: 227-238.

Buentello A.J., Gatlin D.M. and W.H. Neill, 2000. Effects of water temperature and dissolved oxygen on daily feed consumption, feed utilization and growth of channel catfish (Ictalurus punctatus). Aquaculture, 182(3-4):339-352.

De Silva S. S. and T. A. Anderson, 1995. Fish nutrition in aquaculture. London: Chapman \& Hall.

Degani G., Viola S. and Y. Yehuda, 1997. Apparent digestibility of protein and carbohydrate in feed ingredients for adult tilapia (Oreochromis aureus $\times 0$. niloticus). Isr. J. Aquacult. Bamidgeh, 49 (3): 115-123.

Goddard J. S. and E. McLean, 2001. Acid-insoluble ash as an inert reference material for digestibility studies in tilapia, Oreochromis aureus. Aquaculture, 194(1-2): 93-98.

Gurure R. M., Moccia R. D. and J. L. Atkinson, 1996. Apparent digestibility and amino acid availability of six feed ingredients by Arctic charr (Salvelinus alpinus). Bull. Aquacult. Assoc. Can., 1: 32-34.

FAO, 2016. The State of World Fisheries and Aquaculture 2016. Contributing to food security and nutrition for all. Rome. 200 pp.

Hasan, M. R., 2007. Economics of aquaculture feeding practices in selected Asian countries. FAO Fisheries Technical Paper No. 505. Rome, FAO. 205 pp.

Helrich K., 1990. Official methods of analysis of the Association of Official Analytical Chemists (15th ed. / edited by Kenneth Helrich. ed.). Arlington, Va.: Association of Official Analytical Chemists.

Johansson L., Kiessling A., Asgard T. and L. Berglund, 1995. Effects of ration level in rainbow trout, Oncorhynchus mykiss (Walbaum), on sensory characteristics, lipid content and fatty acid composition. Aquacult. Nutr., 1(1): 59-66.

Karakoc, F.T., Okumus, I., İsmen, A., Ozdemir, A., Akhan, S., Deniz, H., Demirbas, M., Eke, S., Bahadırlar, Y., Tüfekci, V., Tolun, L., Tüfekci, H., Olgun, A., Bascinar, N.S., Buyukates, Y., Turkoglu, M., Akbulut, B., Alkan, A., Ogut, H., Feyzioglu, M., Gozler, A.M., Sahin, C., Eruz, C., Verep, B., Sahin, S.A., Yandi, I., Celebi, R., Serdar, S., Onal, U., Ergun, S., Erdem, Z., K. Erciyes, 2010. Determination of Effects of Fish Cage Cultures on Marine Ecosystems. Final Report, TUBITAK-MAM YDABAG-105G038, Gebze-Kocaeli, Turkey.

Lopez Alvarado, J., 1997. Aquafeeds and the environment. In: Tacon, A., Basurco, B. (Eds.), Feeding Tomorrow's Fish. Cah. Options Mediterr., vol. 22. Institut Agronomique Mediterraneen de Zaragoza (CIHEAM), Zaragoza, Spain, 275-289 pp.

Oliva-Teles, A., Enes, P., H. Peres, 2015. Replacing fishmeal and fish oil in industrial aquafeeds for carnivorous species. In: Davies, A. (Ed.), Feed and Feeding Practices in Aquaculture. Woodhead publishing series in food science, technology and nutrition. Woodhead publishing, Oxford, 203-233 pp. 
Rasmussen R.S. and A. Jokumsen, 2009. Digestibility in selected rainbow trout families and relation to growth and feed utilisation. Aquac. Int., 17: 187-197.

Shahat T. M., 1993. Digestibility determination in Nile catfish fingerlings using internal and external markers. Vet. Med. J. Giz., 41: 83-91.

Storebakken T. and E. Austreng, 1987. Ration Level for Salmonids. II. Growth, Feed Intake, Protein Digestibility, Body Composition, and Feed Conversion in Rainbow-Trout Weighing 0.5-1.0 Kg. Aquaculture, 60(3-4): 207-221.

Tacon A. G. J. and A. M. P. Rodriguez, 1984. Comparison of Chromic Oxide, Crude Fiber, Polyethylene and Acid-Insoluble Ash as Dietary Markers for the Estimation of Apparent Digestibility Coefficients in Rainbow-Trout. Aquaculture, 43(4): 391-399.

Thomas M. and A. F. B. van der Poel, 1996. Physical quality of pelleted animal feed. I. Criteria for pellet quality. Anim. Feed Sci. Technol., 61(1-4): 89-112.

TurkStat, 2015. Annual Report: The state of Turkish fisheries and aquaculture 2014. Ankara, Turkey: Turkish Statistic Board.

White, P., 2013. Environmental consequences of poor feed quality and feed management. In M.R. Hasan and M.B. New, eds. On-farm feeding and feed management in aquaculture. FAO Fisheries and Aquaculture Technical Paper No. 583. Rome, FAO. 553-564 pp. 